\title{
Heat Islands in the city of San Francisco de Campeche: Detection and solution
}

\section{Islas de calor en la ciudad de San Francisco de Campeche: Detección y solución}

CANUL-TURRIZA, Román Alejandro†*, BARRERA-LAO, Francisco Javier and ALDANANARVÁEZ, Gabriela Patricia

Universidad Autónoma de Campeche, Faculty of Engineering

ID $1^{\text {st }}$ Author: Román Alejandro, Canul-Turriza / ORC ID: 0000-0003-2081-9913, CVU CONACYT ID: 546727

ID $2^{\text {nd }}$ Coauthor: Francisco Javier, Barrera-Lao / ORC ID: 0000-0001-5144-8305

ID $3^{\text {rd }}$ Coauthor: Gabriela Patricia, Aldana Narváez / ORC ID: 0000-0002-9794-4395

Received April 18, 2020; Accepted June 30, 2020

\begin{abstract}
This paper presents the identification of heat islands in the city of San Francisco de Campeche, period 1990 - 2020 and their relationship with changes in the vegetation cover areas. To identify the heat islands in the city, 6 Landsat 5 (TM), 7 (TM) and 8 (OIL) images were obtained from the USGS database (http://earthexplorer.usgs.gov/). In geographic information software, soil temperature was calculated from a mathematical algorithm applied to thermal infrared bands 6 and 10, in addition, the Normalized Difference Vegetation Index (NDVI) was calculated, in order to find a relationship between changes in temperature and vegetation cover. It was found that the green areas have reduced their surface by more than $50 \%$ and the soil temperature has increased up to $7^{\circ} \mathrm{C}$.
\end{abstract}

Landsat, Campeche, Heat Islands

\begin{abstract}
Resumen
Este trabajo presenta la identificación de islas de calor en la ciudad de San Francisco de Campeche, período 1990 - 2020 y su relación con cambios en las áreas de cobertura vegetal. Para identificar las islas de calor en la ciudad, se obtuvieron 6 imágenes Landsat 5 (TM), 7 (TM) y 8 (OIL) de la base de datos del USGS (http://earthexplorer.usgs.gov/). En software de información geográfica se calculó la temperatura del suelo a partir de un algoritmo matemático aplicado a las bandas de infrarrojos térmicos $6 \mathrm{y}$ 10, además, se calculó el Índice de Vegetación de Diferencia Normalizada (NDVI), con el fin de encontrar una relación entre cambios de temperatura y cobertura vegetal. Se encontró que las áreas verdes han reducido su superficie en más de un $50 \%$ y la temperatura del suelo ha aumentado hasta los $7^{\circ} \mathrm{C}$.
\end{abstract}

Landsat, Campeche, Isla de calor

Citation: CANUL-TURRIZA, Román Alejandro, BARRERA-LAO, Francisco Javier and ALDANA-NARVÁEZ, Gabriela Patricia. Heat Islands in the city of San Francisco de Campeche: Detection and solution. ECORFAN Journal-Republic of Paraguay. 2020. 6-10: 16-20

\footnotetext{
* Correspondence to Author (email: roacanul@uacam.mx)

$\dagger$ Researcher contributing as first author.
} 


\section{Introduction}

Urbanization and industrialization offer a better quality of life, which translates into greater comfort; however, they also induce many problems for human beings, such as global warming, industrial waste and pollution. In addition to the global impacts that are generated, there is an imbalance in urban areas where the increase and excess of industrial activities and the use of synthetic construction materials are more frequent; as a result, the environment is affected and the population is more vulnerable to problems associated with urbanization (Rizwan et al. 2008).

One of the phenomena generated in cities are the so-called Urban Heat Islands. The Urban Heat Islands (UHI) is a phenomenon referred to the presence of warmer air in certain areas of a city compared to its surroundings and that can be exacerbated in coastal cities due to the climatic variations that occur. Heat islands have acquired particular relevance in recent years due to the growing impact of climate change and its variability in urban spaces; therefore, these thermal anomalies aggravate the picture of pollution and degradation of the quality of the habitat (Fuentes Pérez 2014).

This heat is mainly due to the heat stored and radiated by the constant growth of urban structures (Rizwan et al. 2008); large amounts of solar radiation are stored and re-irradiated, mainly in areas with a higher population concentration due to construction material and the decrease in vegetated areas due to changes in land use; In addition, a high roughness reduces the removal of heat by convection.

It has been suggested to reduce anthropogenic heat release and make design changes, use of trees, cooler roofs, suitable building material and proper building design to reduce high heat intensity (Rizwan et al. 2008). Of all the proposed measures, the reforestation of cities is a highly promising solution.

The main objective of this article is to quantify the increase in temperature in the City of San Francisco de Campeche for the period 1990 - 2020 and its relationship with changes in land use. The areas with the highest temperature increase were identified and the construction of green corridors is proposed as a mitigation measure.

\section{Study area}

The city of San Francisco de Campeche is the main head of the state, which has a territorial extension of $3,410.64 \mathrm{~km} 2$ ( $6 \%$ of the total state territory). It is located at the coordinates $19^{\circ} 50^{\prime}$ $41^{\prime \prime} \mathrm{N}$ y $90^{\circ} 32^{\prime} 23$ ' $\mathrm{W}$ with an average altitude of 5 meters above sea level. According to the count of INEGI (2005) has a population of 211 671 inhabitants (28\% of the state), which represents $88.6 \%$ of the total municipality.

In San Francisco de Campeche, the average annual temperature is $27{ }^{\circ} \mathrm{C}$, with maximum levels in summer with an average of $28^{\circ} \mathrm{C}$ and a historical maximum temperature of $43{ }^{\circ} \mathrm{C}$. It has a warm - humid climate with three seasons defined as follows: from June to the end of September is the rainy season; October to January is the "Nortes" season or winter storms and the dry season from February to May (Rivera Arriaga et al. 2012). Average annual rainfall is $1096.7 \mathrm{~mm}$, with the highest precipitation from July to September (CONAGUA, 2004).

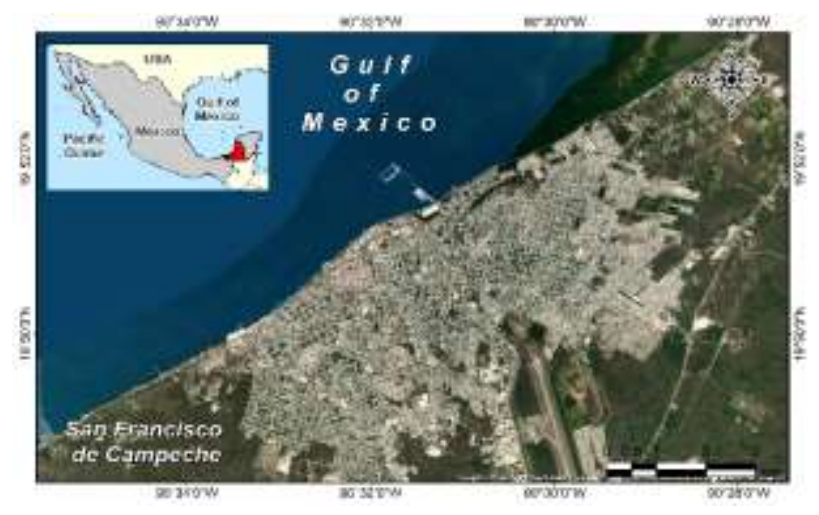

Figure 1 Study area

\section{Methodology}

Calculating the intensity of UHIs requires calculating the Land Surface Temperature (LST). For this, the thermal bands of satellite images were used and were processed by means of a geographic information system; since they are a main tool for the treatment of environmental problems that exist in Latin American cities, due to the scarce information available and the precariousness of the monitoring and observation systems of environmental changes. 
For the city of San Francisco de Campeche, 14 Landsat 5 (TM), 7 (TM) and 8 (OLI) images were used for the period 1990 2020 obtained from the USGS database. (http://earthexplorer.usgs.gov/); the analyzed images belong to the months of April or May, in order to characterize the temperature of the dry season. Band 6 was used for TM images and band 10 was used for OLI images. (Li et al. 2016). Briefly, the satellite radiances of the thermal bands were converted to brightness temperatures at the sensor using the equation (1):

$$
\mathrm{T}_{\mathrm{B}}=\frac{\mathrm{K}_{2}}{\ln \left(\frac{\mathrm{K}_{1}}{\mathrm{~L}_{\lambda}}+1\right)}
$$

Where $T_{B}$ is the brightness temperature of the sensor in Kelvin; $L \mathrm{~L}$ is equal to a satellite radiance derived from the preprocessing step; the values of $K_{1}$ y $K_{2}$ are obtained from the metadata of the respective Landsat images. The generated gloss temperature values were then converted to LST with emissivity correction $\left(T_{S}\right)$ in Kelvin using the equation (2):

$$
\mathrm{T}_{\mathrm{S}}=\frac{\mathrm{T}_{\mathrm{B}}}{1+\left[\left(\lambda \times \frac{\mathrm{T}_{\mathrm{B}}}{\alpha}\right) \ln \varepsilon\right]}
$$

Where $\lambda$ is the wavelength of the emitted radiance equal to11.5 $\mu \mathrm{m} ; \quad \alpha=$ $\frac{h c}{b}\left(1.438 \times 10^{-2} m k\right), b$ refers to Boltzman's constant as $1.38 \times 10^{-23} \mathrm{~J} / K$; h is Planck's constant which is equal to $6.626 \times 10^{-34} \mathrm{JS}$; c refers to the speed of light $2.998 \times 10^{8} \mathrm{~m} / \mathrm{s}$ and $\varepsilon$ is the surface emissivity.

San Francisco de Campeche is a heterogeneous region; therefore, it was necessary to consider the effect of surface emissivity $\varepsilon$ when estimating the LST. Here, the normalized difference vegetation index (NDVI) threshold method was applied to different land cover classes; for this, the red and near infrared 1 bands were used. First, the emissivity of the pixels of bodies of water was assigned as 0.990 (Deng and $\mathrm{Wu}$ 2013). Then, an emissivity of 0.985 was assigned to each pixel with a normalized difference vegetation index value $(\mathrm{NDVI}) \geq 0.5$. These pixels were considered to be fully vegetated. Finally, for the remaining pixels (that is, covered with sparse and accumulated vegetation), an emissivity was calculated based on equations 3 to 5 (Deng and Wu 2013).

$$
\varepsilon_{\text {mix }}=\varepsilon_{\mathrm{v}} \mathrm{P}_{\mathrm{v}}+\varepsilon_{\mathrm{n}}\left(1-\mathrm{P}_{\mathrm{v}}\right)+\mathrm{C}_{\mathrm{i}}
$$

ISSN-On line: $2414-4827$

ECORFAN® All rights reserved.

$$
\begin{aligned}
& \mathrm{P}_{\mathrm{V}}=\left(\frac{\mathrm{NDVI}-\mathrm{NDVI}_{\min }}{\mathrm{NDVI}_{\mathrm{max}}-\mathrm{NDVI}_{\min }}\right)^{2} \\
& \mathrm{C}_{\mathrm{i}}=\left(1-\varepsilon_{\mathrm{n}}\right)\left(1-\mathrm{P}_{\mathrm{V}}\right) \mathrm{F} \varepsilon_{\mathrm{V}}
\end{aligned}
$$

Where $\varepsilon_{V}=0.985$ (vegetation) and $\varepsilon_{n}=0.92$ (urban surface) (Li et al. 2011); $N D V I_{\max } \mathrm{y} N D V I_{\min }$ are the values of the complete vegetation and no vegetation respectively; $P_{v}$ is the NVDI scaling / splitting vegetation cover, $C_{i}$ is the effect of the geometric distribution of natural surfaces and internal reflections (Sobrino et al., 2004) and $\mathrm{F}=0$. which refers to the shape factor for the geometric distribution. The LST calculated in Kelvin was then converted to Celsius for easy interpretation.

\section{Results}

Between 1990 and 2020 there was a physical expansion of the city that was oriented in all directions, mainly caused by the invasion of land that was transformed into residential areas. This expansion is also related to the increase in the number of inhabitants, which is why the growth is caused by the need for housing. It was found that the green areas of the city have reduced their surface by little more than $50 \%$ for the period 1990 - 2020.

Due to the presence of cloud cover and gaps in some of the Landsat images, the images analyzed here had to meet the criteria of having less than $10 \%$ surface coverage with clouds and no gaps. Figure 2 shows a map of the distribution of surface temperatures for the year 1990, it is observed that the maximum temperatures recorded correspond to $35^{\circ} \mathrm{C}$ on average and are located in the downtown area of the city, as well as in some points where there are constructions in process or modifications of land use such as the change from a natural area to cultivation areas (polygons in Figure 2).

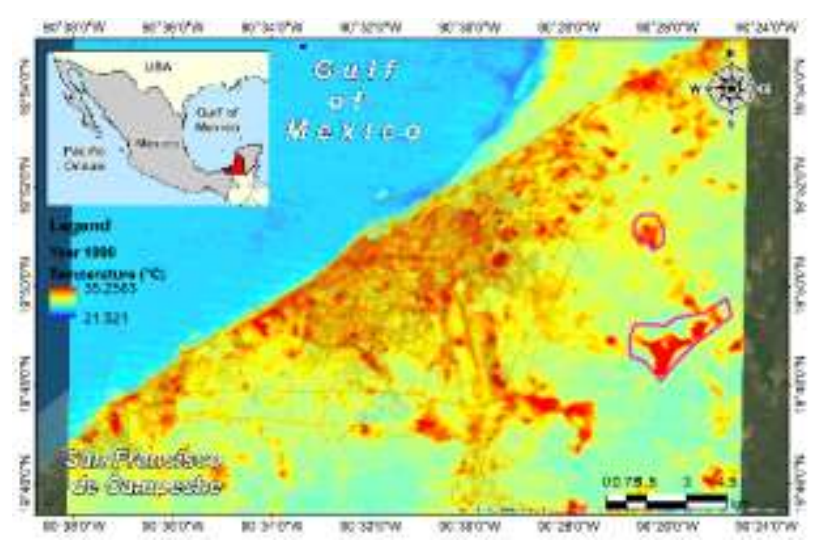

Figure 2 Temperature distribution map for the year 1990

CANUL-TURRIZA, Román Alejandro, BARRERA-LAO, Francisco Javier and ALDANA-NARVÁEZ, Gabriela Patricia. Heat Islands in the city of San Francisco de Campeche: Detection and solution. ECORFAN Journal-Republic of Paraguay. 2020 
In Figure 3, a map of the distribution of surface temperatures for the year 2020 is presented; Maximum temperatures are close to $42^{\circ} \mathrm{C}$ and minimum (on the map scale) of 17.9 ${ }^{\circ} \mathrm{C}$, the latter due to the presence of cloudiness over the city. It is appreciated that the periphery is where there are areas with higher temperatures than their surroundings; Areas such as the historic center and avenues that have been rebuilt in the last 5 years, a decrease in vegetation coverage has been observed and as a consequence an increase in surface temperature compared to previous years, which is why they present areas that we can call Heat Islands.

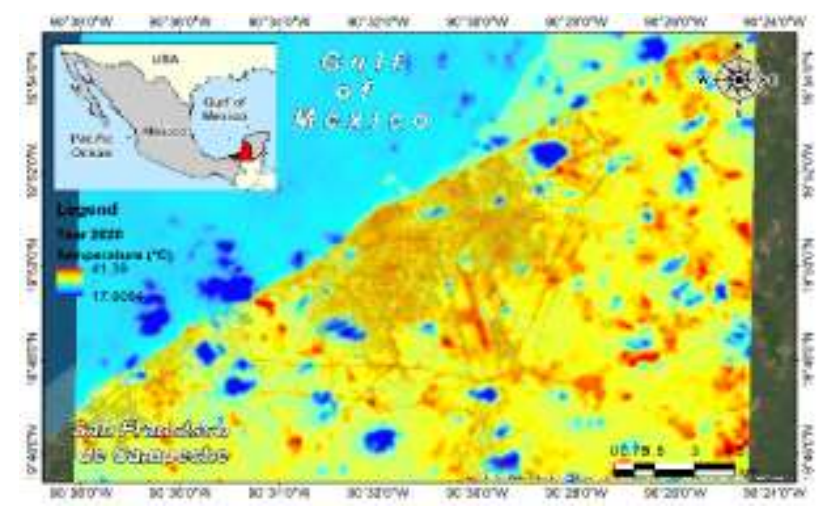

Figure 3 Temperature distribution map for the year 2020

16 points of interest were identified within the city that could make it possible to assess whether or not there has been an increase in temperature; In Figure 4, the location map of the points is presented.

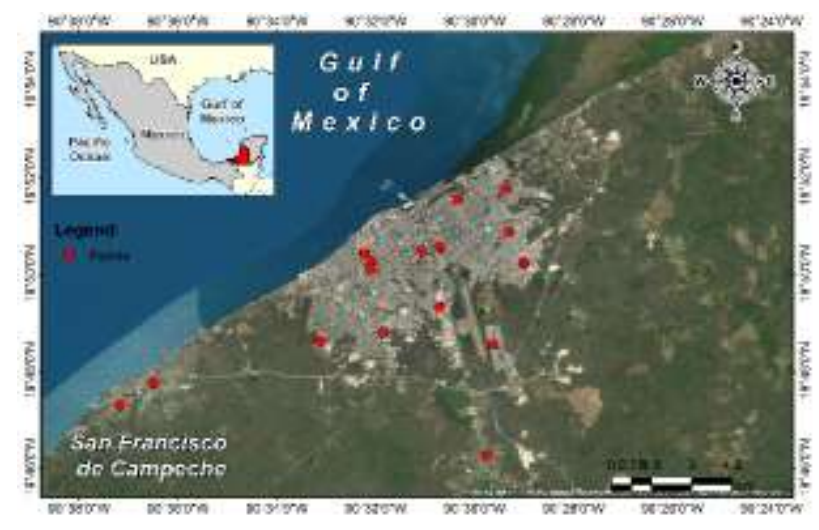

Figure 4 Location of sampling points

And in Figure 5, the graphs of the temperature values recorded for the points are presented. To obtain a better representation of the temperature changes, it was decided to present the results in periods of 5 years, whenever possible.
It is observed that from the period 1990 to 2011 the temperature in most of the points has a variation range of $\pm 1{ }^{\circ} \mathrm{C}$; while between 2011 and 2015, the temperature had an average increase of $5^{\circ} \mathrm{C}$; With the exception of point 8 , in which a decrease is observed, this due to the presence of a cloud in the analyzed image. Point 15 is observed to have an increase of up to $7{ }^{\circ} \mathrm{C}$ compared to 2011 .

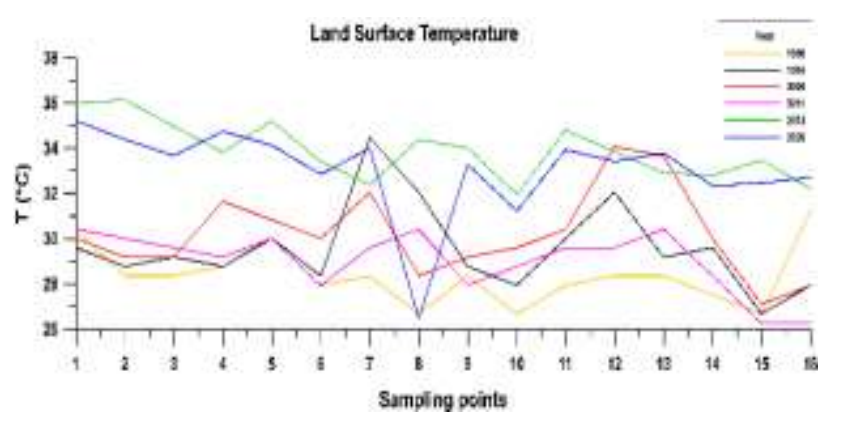

Figure 5 Sampling points and associated temperature for the years under analysis

\section{Conclusions}

The increase in soil temperature in the city of San Francisco de Campeche has a direct relationship with the reduction of vegetated areas; reaching increases of up to $7^{\circ} \mathrm{C}$ in a period of 30 years. With this proportion of temperature increase of $0.23^{\circ} \mathrm{C}$ per year, and if the conditions of urban growth are maintained without planning or conservation of the natural environment in the next 10 years, temperatures of up to $40^{\circ} \mathrm{C}$ would be expected in the city in the dry season.

Although the increase may seem negligible, it is this increase in temperature that leads to an increase in the use of air conditioning equipment, causing an increase in energy demand and the generation of greater atmospheric pollutants $\left(\mathrm{CO}_{2}, \mathrm{NO}, \mathrm{SO}_{2}, \mathrm{PM}\right)$; on the other hand, the occurrence of diseases increases, especially respiratory ones. Furthermore, the UHIs generate a convective ascent over the city, generating a low relative atmospheric pressure that accentuates the local circulation of air, causing the displacement of polluted air masses to other sectors of the city.

Therefore, it is proposed to evaluate the construction of green corridors in strategic points of the city as a measure of mitigation and reduction of heat islands. 
These corridors should be located mainly in areas with a greater influx of people such as parks, avenues and other recreation areas, as well as highly dense housing complexes.

\section{References}

Deng, Chengbin, and Changshan Wu. 2013. Examining the impacts of urban biophysical compositions on surface urban heat island: A spectral unmixing and thermal mixing approach. Remote Sensing of Environment 131: 262-274. doi:https://doi.org/10.1016/j.rse.2012.12.020.

Fuentes Pérez, Carlos Alberto. 2014. Islas de calor urbano en Tampico, México. Impacto del microclima a la calidad del hábitat. Revista Electrónica Nova Scientia 7: 495-515.

INEGI. 2005. Censo de Población y Vivienda 2005.

Li, Junxiang, Conghe Song, Lu Cao, Feige Zhu, Xianlei Meng, and Jianguo Wu. 2011. Impacts of landscape structure on surface urban heat islands: A case study of Shanghai, China. Remote Sensing of Environment 115: 32493263.

doi:https://doi.org/10.1016/j.rse.2011.07.008.

Li, Xiaoxiao, Wenwen Li, A Middel, S L Harlan, A J Brazel, and B L Turner. 2016. Remote sensing of the surface urban heat island and land architecture in Phoenix, Arizona: Combined effects of land composition and configuration and cadastral-demographic-economic factors. Remote Sensing of Environment 174: 233-243. doi:https://doi.org/10.1016/j.rse.2015.12.022.

Rivera Arriaga, Evelia, L. Alpuche Gual, M. Negrete Cardoso, Juan Carlos Nava Fuentes, E. Lemus Pablo, and C. Arriaga Zepeda. 2012. Programa de Manejo Costero Integrado para el Saneamiento de la Bahía de San Francisco de Campeche. Campeche, México: Universidad Autónoma de Campeche.

Rizwan, Ahmed Memon, Leung Y C Dennis, and Chunho Liu. 2008. A review on the generation, determination and mitigation of Urban Heat Island. Journal of Environmental Sciences 20: $120-128$. doi:https://doi.org/10.1016/S10010742(08)60019-4. 